\title{
CHITOSAN/CLAY BIONANOCOMPOSITES:
}

\section{STRUCTURAL, ANTIBACTERIAL, THERMAL AND SWELLING PROPERTIES}

\author{
NEVIN CANKAYA and RESUL SAHIN \\ Department of Chemistry, University of Usak, Usak, Turkey \\ $\square$ Corresponding author: Nevin Çankaya,nevin.cankaya@usak.edu.tr
}

Received July 24, 2018

\begin{abstract}
In this study, $\mathrm{Na}^{+}$Montmorillonite (C Na), Nanoclay 1-135 (C 10A) and Nanoclay 1-140 (C 15A) were used as nanofiller in the preparation of chitosan biopolymer/clay nanocomposites. For this purpose, a dilute acetic acid solution was used as solvent for dissolving and dispersing the chitosan and the clays, respectively, and chitosan/C Na, chitosan/C 10A and chitosan/C 15A bionanocomposites were synthesized. Bionanocomposites were prepared by the solution induced intercalation method with various percentages of the three clay types. Then, the properties of the bionanocomposites were investigated as the loading of the clays was varied: $1 \%, 3 \%, 5 \%$, and $7 \%$. The characterization of the composites was done chemically by FTIR, physically by XRD and SEM, and thermally by TGA/DTA. Also, swelling tests of the clay and bionanocomposites were carried out. In addition, their antimicrobial properties were investigated towards Staphylococcus aureus and Escherichia coli. The highest antimicrobial activity was found for the chitosan/C 10A biocomposite. It was observed that the thermal stability of the bionanocomposites increased with increasing amount of clay added to chitosan. All the chitosan/clay biocomposites were observed by XRD and SEM, which revealed exfoliation behavior.
\end{abstract}

Keywords: chitosan, bionanocomposite, biodegradable polymers, clay, organoclay, antimicrobial property, thermal stability, swelling property

\section{INTRODUCTION}

Chitosan is one of the most common biopolymers in nature, and it is obtained by alkaline deacetylation of chitin. It can easily be obtained by processing residue from a large portion of marine organisms. Due to its superior properties, such as biocompatibility, biodegradability and low toxicity, it can be applied in many areas, such as medical, cosmetics, agriculture and recycling. ${ }^{1}$ Recently, chitosan has been used as adsorbent in the removal of heavy metals and dyes. ${ }^{2}$ Biologically compatible chitosan is also used as an appropriate matrix in various drug formulations. Various medicines are placed in a chitosan matrix (film, microcapsules, coated tablets, etc.). There are drugs trapped in chitosan in different forms. ${ }^{1,3}$ In acidic medium, the $\mathrm{NH}_{2}$ group is in the form of $\mathrm{NH}_{3}{ }^{+}$and it electrostatically interacts with the anionic groups in the environment. In the protonated state, it exhibits cationic polyelectrolyte behavior, forms viscous solutions, and interacts with oppositely charged molecules and surfaces. Chitosan interacts with negatively charged drugs, polymers, bioactive molecules and organoclay due to the cationic nature of its free amine group $-\mathrm{NH}_{3}{ }^{+4,5}$

The development of chitosan-layered silicate biocomposites by introducing chitosan chains into silicate interlayers can improve the properties of the obtained material. Recently, polymer nanocomposites have received considerable attention due to their superior thermal, mechanical and electrical properties, compared to those of the polymer itself. ${ }^{6}$ Biodegradable polymer nanocomposite materials have better swelling behavior and drug loading efficiency, as well as better controlled release behavior and mechanical properties, compared to the polymer matrix. ${ }^{1}$ Mixing a polymer with an organoclay forms a micro-scale composite, where the clay is used only as a filler. Ideal composition types are intercalation and exfoliation. When intercalated, a Cellulose Chem. Technol., 53 (5-6), 537-549(2019) 
small amount of polymer is added between the clay layers to expand the interlayer spacing and thus form a well-regulated multilayer structure. In the case of exfoliation, the clay layers are completely separated and the individual layers are distributed along the polymer matrix. Depending on the amount and the type of clay, intercalation or exfoliation occurs. ${ }^{6}$ High clay filler levels $(>50$ $\mathrm{wt} \%$ ) increase the product density and may cause deterioration of properties because of the interface mismatch between the filler and the organic matrix. Nanocomposite materials are polymers filled with particles in which at least one dimension (i.e., length, width, or thickness) of the dispersed particles is within the nanometer range. For this reason, more interfacial interaction between the nanoparticles and the polymer matrix is expected. The most successful results have been obtained for composite materials with low filler content of 3-5\%.

The production of biodegradable polymers by the addition of inorganic particles is a new technology, which is of special importance considering environmental concerns. The development of biodegradable plastics is an approach to solving plastic waste disposal. ${ }^{8}$ Synthesizing composites from various clay types and biopolymers, such as pectin and chitosan, results in hydrogels with high absorbtivity. ${ }^{9}$

In this study, bionanocomposite systems were prepared from montmorillonite clay and chitosan, and their thermal, antibacterial and swelling behaviors were investigated. Also, the effect of different types of montmorillonite on the chitosan biopolymer matrix was determined. For this purpose, three major types of montmorillonite and its organoclay were used in this study.

\section{EXPERIMENTAL Materials}

Chitosan, with a degree of deacetylation of $\geq 75 \%$ and average molecular weight of 310.000-375.000 $\mathrm{g} / \mathrm{mol}$, was bought from Sigma-Aldrich. Acetic acid and sodium hydroxide were also purchased from Sigma-Aldrich. The Microbiology Laboratory of the School of Health (Usak University, Turkey) provided standard cultures of the organisms Staphylococcus aureus ATCC 25923 and Escherichia coli ATCC 3521. Double-distilled water was used for the preparation of all the solutions.

Three different nanoclays with trade names of $\mathrm{Na}^{+}$Montmorillonite (MMT), Nanoclay 1-135 and Nanoclay 1-140 were provided by Esan-Eczacıbaşı. $\mathrm{Na}^{+} \mathrm{MMT}$ is a natural bentonite clay modified for higher $\mathrm{Na}^{+}$content, with a particle size range of $<63 \mu$. Two organoclays Nanoclay 1-135 and 1-140, types of $\mathrm{Na}^{+} \mathrm{MMT}$, were modified with a quaternary ammonium salt. The organic modifier of Nanoclay 1135 is dimethyl, benzyl, hydrogenated tallow, quaternary ammonium cation, with the particle size range of $<15 \mu$. The organic modifier of Nanoclay 1140 is dimethyl, dihydrogenated tallow, quaternary ammonium cation, with the particle size range of $<20$ $\mu$, where tallow is $\sim 65 \% \mathrm{C} 18, \sim 30 \% \mathrm{C} 16, \sim 5 \% \mathrm{C} 14$. Long chain alkyl groups (tallow) are widely used to expand the interlayer spacing. Thus, there is compatibility between the polymer matrix and the hydrophilic organoclay surface. The chemical properties of $\mathrm{Na}^{+} \mathrm{MMT}$, Nanoclay 1-135 and 1-140 are given in Table 1. The XRD curves of the nanoclay provided by Esan-Eczacıbaşı are given Figure 1, where LOI stands for loss on ignition. XRD measurements of the clays were again taken to compare the results with those obtained for the bionanocomposites.

Table 1

Chemical properties of $\mathrm{Na}^{+} \mathrm{MMT}$, Nanoclay 1-135 and 1-140

\begin{tabular}{lccc}
\hline Chemical analysis & $\begin{array}{c}\mathrm{Na}^{+} \mathrm{MMT} \\
(\%)\end{array}$ & $\begin{array}{c}\text { Nanoclay 1-135 } \\
(\%)\end{array}$ & $\begin{array}{c}\text { Nanoclay 1-140 } \\
(\%)\end{array}$ \\
\hline $\mathrm{Al}_{2} \mathrm{O}_{3}$ & $13.00 \pm 1.00$ & $6.0 \pm 1.0$ & $6.0 \pm 1.0$ \\
$\mathrm{SiO}_{2}$ & $73.00 \pm 1.50$ & $45 \pm 2.0$ & $44 \pm 1.0$ \\
$\mathrm{Na}_{2} \mathrm{O}$ & $2.50 \pm 0.50$ & $0.6 \pm 0.2$ & $0.6 \pm 0.2$ \\
$\mathrm{Fe}_{2} \mathrm{O}_{3}$ & $0.70 \pm 0.20$ & $0.5 \pm 0.2$ & $0.4 \pm 0.2$ \\
$\mathrm{TiO}_{2}$ & $0.07 \pm 0.02$ & $0.05 \pm 0.02$ & $45 \pm 2.0$ \\
$\mathrm{CaO}$ & $1.50 \pm 0.50$ & $1.0 \pm 0.1$ & $0.4 \pm 0.1$ \\
$\mathrm{MgO}$ & $3.00 \pm 0.30$ & $1.3 \pm 0.2$ & $1.4 \pm 0.2$ \\
$\mathrm{~K}$ & - & $1.0 \pm 0.1$ & $0.3 \pm 0.1$ \\
$\mathrm{LOI}$ & $7.00 \pm 1.00$ & $40 \pm 2.0$ & $45 \pm 2.0$ \\
\hline
\end{tabular}



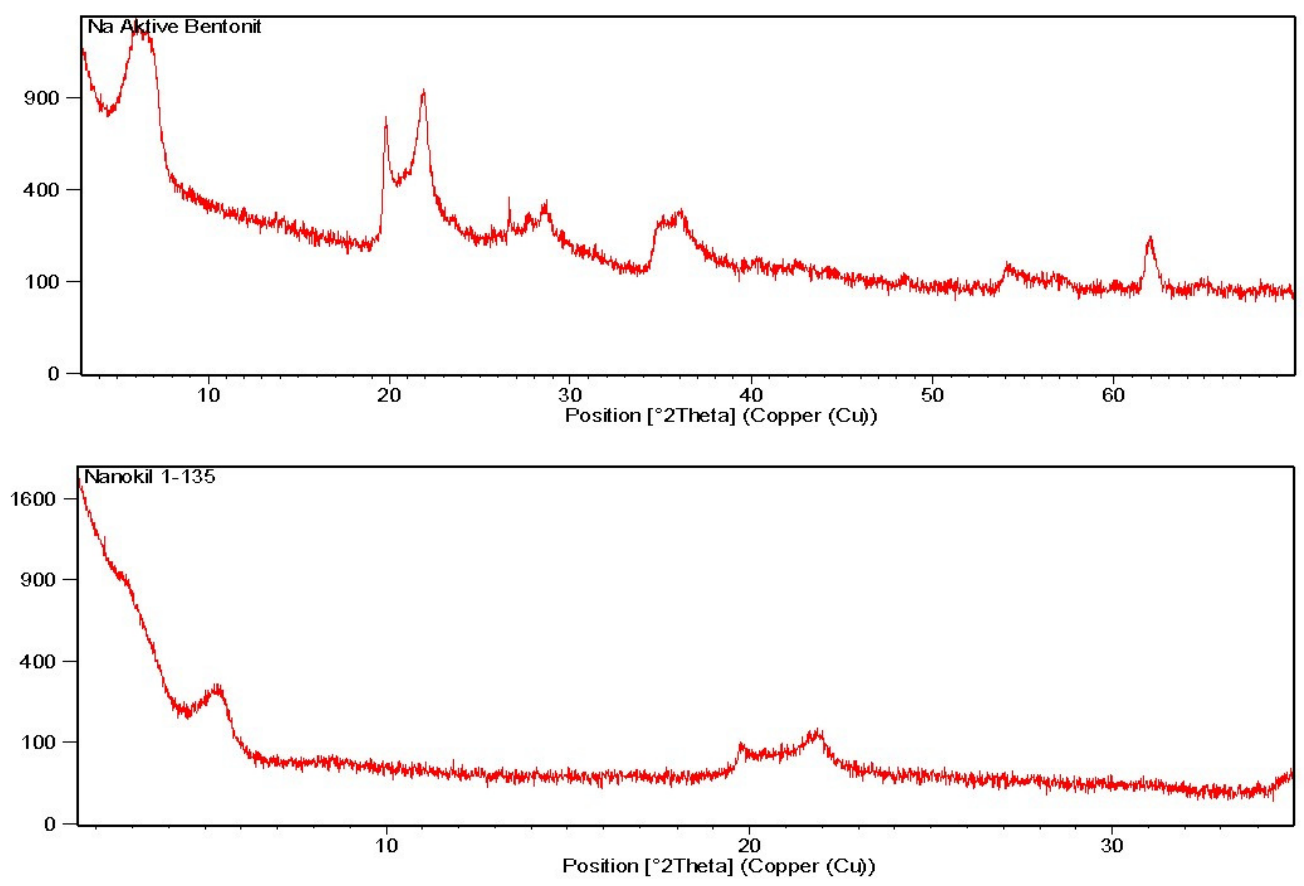

a)

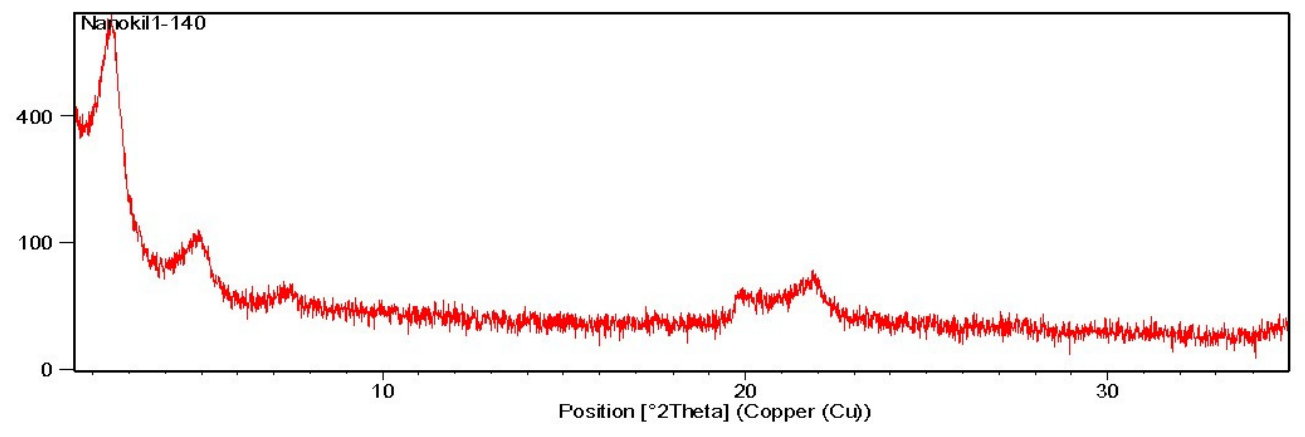

Figure 1: XRD patterns of $\mathrm{Na}^{+} \mathrm{MMT}$ (a), Nanoclay 1-135 (b) and Nanoclay 1-140 (c), respectively

\section{Preparation of clay/chitosan nanocomposites}

Chitosan/clay bionanocomposites were synthesized by the solution blending method. $2 \mathrm{~g}$ of chitosan were dissolved in $2 \%$ acetic acid solution. $1 \%, 3 \%, 5 \%$ and $7 \%$ by weight of chitosan was swollen in distilled water. Clay suspensions $\left(\mathrm{Na}^{+} \mathrm{MMT}(\mathrm{C} \mathrm{Na})\right.$, Nanoclay 1-135 (C 10A) and Nanoclay 1-140 (C 15A)) were slowly added to the chitosan solution and mixed at 750 rpm for 24 hours at $60{ }^{\circ} \mathrm{C}$, dried and washed with $1 \%$ $\mathrm{NaOH}$ until neutralization, and finally washed with purified water to remove the acetate. ${ }^{10-12}$ The bionanocomposites synthesized with various percentages of the three clay types were beaten and sifted through a 20 micron sieve.

\section{Instrumental measurements of bionanocomposite}

The FTIR spectra of all the samples were acquired with a Perkin Elmer Spectrum Two (UATR) IR spectrometer in the range of $4000-450 \mathrm{~cm}^{-1}$. XRD patterns were obtained using a Bruker Axs D8
Advance diffractometer, with a back monochromator and a $\mathrm{Cu}$ target and $\mathrm{K} \alpha(\lambda=1.5418 \mathrm{~nm})$ in $2 \theta=10-45^{\circ}$ (step of $0.01^{\circ}$, at room temperature). Scanning electron microscopy images were recorded with a Zeiss Evo LS10 at $25 \mathrm{kV}$. Thermal analyzes were obtained using a Hitachi 7000 TGA/DTA simultaneous system, at a heating rate of $10{ }^{\circ} \mathrm{C} \mathrm{min}{ }^{-1}$ in nitrogen atmosphere.

\section{In vitro antimicrobial activity study \\ Halo test method}

The halo test method was used to determine the antibacterial activity of chitosan, clays and bionanocomposites. Staphylococcus aureus (S. aureus ATCC 25923) and Escherichia coli (E. coli ATCC 3521) were used as test bacteria and all the glassware was sterilized in an autoclave before the tests. Cell densities were adjusted according to the blur of 0.5 MacFarland (108 microorganisms/mL) after incubation at $37{ }^{\circ} \mathrm{C}$ for one day in nutrient broth. The sterile swab was immersed in the medium containing the bacterial 
suspension. Diffusion was done to cover the entire surface of MHA (Muller Hinton agar) Petri dishes. Samples of $0.1 \mathrm{~g}$ were placed on the surface, and then incubated for 1 day at $37{ }^{\circ} \mathrm{C}$. At the end of the incubation period, it was observed whether or not a zone of inhibition was formed around the discs.

\section{Agar dilution test method}

The agar dilution method was performed using standard S. aureus ATCC 25923 and E. coli ATCC 3521. Test bacteria were activated by incubating in nutrient broth liquid medium for 24 hours at $37{ }^{\circ} \mathrm{C}$, and then cell densities were adjusted according to the blur of 0.5 MacFarland (108 microorganisms $/ \mathrm{mL}$ ). For this purpose, the sterile swab was immersed in the medium containing bacteria and planted to cover the entire surface of MHA Petri dishes. $0.1 \mathrm{~g}$ of the test substance was suspended in $1000 \mu \mathrm{L}$ of DMSO (dimethyl sulfoxide), then $20 \mu \mathrm{L}$ and $10 \mu \mathrm{L}$ were impregnated into the different discs. The disks were placed on Petri plates and incubated for $24 \mathrm{~h}$ at $37{ }^{\circ} \mathrm{C}$. In addition, DMSO was used as a negative control, $\mathrm{S}$ (streptomycin), P (penicillin), VA (vancomycin) and DA (clindamycin) antibiotic discs were used as positive controls.

The antibacterial activity is assessed by the formation of the transparent circle around the material. This circle is formed along the periphery of the material, when it has antibacterial activity. When a material has excellent antibacterial activity, this ring is very broad. ${ }^{13-15}$

\section{Swelling study}

The swelling values of chitosan, clay and polymer/clay bionanocomposite were studied after immersion in distilled water at room temperature and pH 7.4, for 1, 3, 6 and 9 hours. The samples were first dried in an oven, their initial weight $\left(\mathrm{W}_{\mathrm{o}}\right)$ was measured and then were placed into bottles filled with distilled water. The time of immersing the samples was taken as $\mathrm{t}=0$ and measurements were performed at certain time intervals until a stable value was achieved (W) after the samples were filtered with filter paper. The swelling percentage of each sample was calculated by Equation (1): ${ }^{3}$

$\mathrm{Sw}=\frac{\mathrm{W}-\mathrm{Wo}_{0}}{\mathrm{Wo}_{0}} \times 100$

\section{RESULTS AND DISCUSSION FTIR spectroscopy}

Figure 2 shows the FTIR spectra of chitosan, clays and chitosan/clay biocomposites. The spectrum of chitosan shows the characteristic bands at $3360 \mathrm{~cm}^{-1}$ (O-H stretch), $2900 \mathrm{~cm}^{-1}$ (aliphatic C-H stretch), $1380 \mathrm{~cm}^{-1}$ (C-H bending vibration), $3290 \mathrm{~cm}^{-1}$ (N-H stretch), $1640 \mathrm{~cm}^{-1}$ (N-H bending vibration), 1025 and $1062 \mathrm{~cm}^{-1}$ (C$\mathrm{O}$ symmetric and asymmetric vibration at $\mathrm{C}-\mathrm{O}-\mathrm{C}$ bonds). The characteristic feature of the clay is that it contains molecules, such as $\mathrm{SiO}_{2}, \mathrm{Al}_{2} \mathrm{O}_{3}$ and $\mathrm{Mg}-\mathrm{O}$. When examining the FTIR spectra of the $\mathrm{C}$ Na clay, it was observed that the $\mathrm{O}-\mathrm{H}$ stretch vibration is located at 3624 and the $\mathrm{O}-\mathrm{H}$ bending vibration at $1450 \mathrm{~cm}^{-1}$, $\mathrm{Si}-\mathrm{O}$ stretching is noted at 1010 and the bending vibration at 514 $\mathrm{cm}^{-1}$, the Al-OH vibration at $913 \mathrm{~cm}^{-1}$ and the $\mathrm{Mg}-\mathrm{O}$ vibration at $475 \mathrm{~cm}^{-1}$. 7,16 The clay peaks are also observed in the spectrum of the $\mathrm{C} 10 \mathrm{~A}$ organoclay, as indicated above. Also, the dimethyl benzyl alkyl chain includes quaternary ammonium chloride used in the modification. The following peaks are attributed to the chemical modifier: aliphatic $\mathrm{N}-\mathrm{CH}_{3}$ vibration at $2840 \mathrm{~cm}^{-1}$, aliphatic $\mathrm{CH}_{2}$ vibration at $1465 \mathrm{~cm}^{-1}$, symmetric and asymmetric $\mathrm{C}-\mathrm{H}$ stretching vibration at 2920 $\mathrm{cm}^{-1}$ and aromatic $\mathrm{C}=\mathrm{C}$ stretching vibration at $1644 \mathrm{~cm}^{-1}$. The $\mathrm{C} 15 \mathrm{~A}$ organoclay includes the dimethyl dialkyl chain quaternary ammonium chloride structures used in the modification, and the spectrum is similar to those of the other clays.

When observing the FTIR spectrum of the chitosan/clay bionanocomposite, it can be remarked that the N-H peak and $\mathrm{O}-\mathrm{H}$ stretching peak from chitosan and $3624 \mathrm{~cm}^{-1} \mathrm{O}-\mathrm{H}$ stretch peak from clay have combined and turned into a broad peak at $\sim 3260 \mathrm{~cm}^{-1}$. Also, the peak at 1025 $\mathrm{cm}^{-1}$ (symmetric $\mathrm{C}-\mathrm{O}$ at $\mathrm{C}-\mathrm{O}-\mathrm{C}$ bonds) in chitosan is overlapped with the peak at $\sim 1005 \mathrm{~cm}^{-1}$ ( $\mathrm{Si}-\mathrm{O}$ stretch) of clay. All of the biocomposites displayed a new peak at $1550 \mathrm{~cm}^{-1}$, which belongs to the $\mathrm{NH}_{3}{ }^{+}$(protonated amine) group, which is adsorbed when the chitosan dissolves in the acid. As the clay concentration increases, these peaks are observed more easily.

\section{XRD measurements}

According to the literature, the characteristic crystalline peak of chitosan is found around $20^{\circ}(\mathrm{d}$ $=0.44 \mathrm{~nm}){ }^{6,17,18}$ The diffraction angle of $\mathrm{C} \mathrm{Na}$ clay was found as $2 \theta=6.5^{\circ}, 20^{\circ}, 22^{\circ}$ (basal spacing $\mathrm{d}=1.36,0.44,0.40 \mathrm{~nm}$ ); the diffraction angle of C 10A organoclay was $2 \theta=5.4^{\circ}, 20^{\circ}$, $22^{\circ}(\mathrm{d}=1.64,0.44,0.40 \mathrm{~nm})$; the diffraction angle of $\mathrm{C} 15 \mathrm{~A}$ organoclay was read at $2 \theta=3^{\circ}$, $4.8^{\circ}, 20^{\circ}, 22^{\circ}(\mathrm{d}=1.47,1.64,0.44,0.40 \mathrm{~nm})$. The XRD patterns of the chitosan, clay/organoclay, and their biocomposites are shown in Figure 3.

The XRD patterns show that the chitosan is spread between the layers and exfoliation occurs. The distribution of the polymer between the silicate layers of the clay made the XRD peak in the nanocomposites unreadable. The absence of 
component-specific peaks in the composite materials can be explained by the fact that the polymer is intercalated between the clay layers, which become so irregular that they cannot give an XRD signal, ${ }^{17,18}$ therefore it can be considered as an exfoliated structure. Also, the small peaks at $6.5^{\circ}, 4.8^{\circ}$ and $5.4^{\circ}$ present in the XRD pattern of the clays are not observed in the biocomposites.

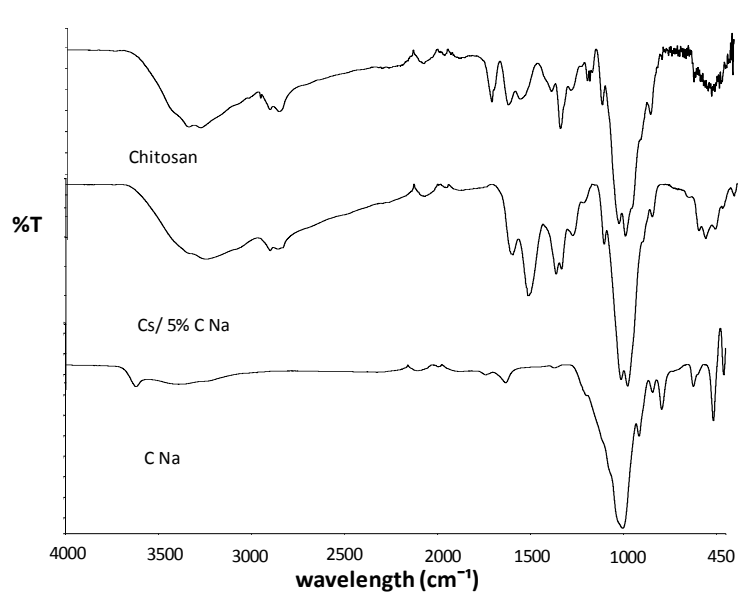

a)

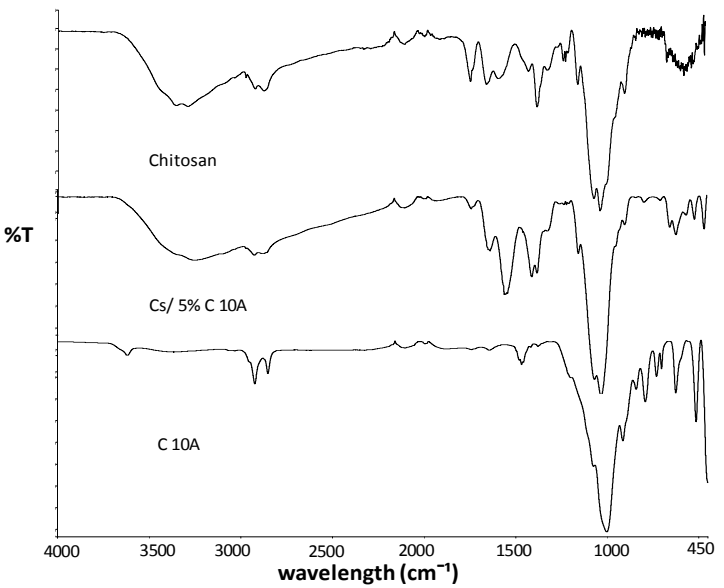

b)

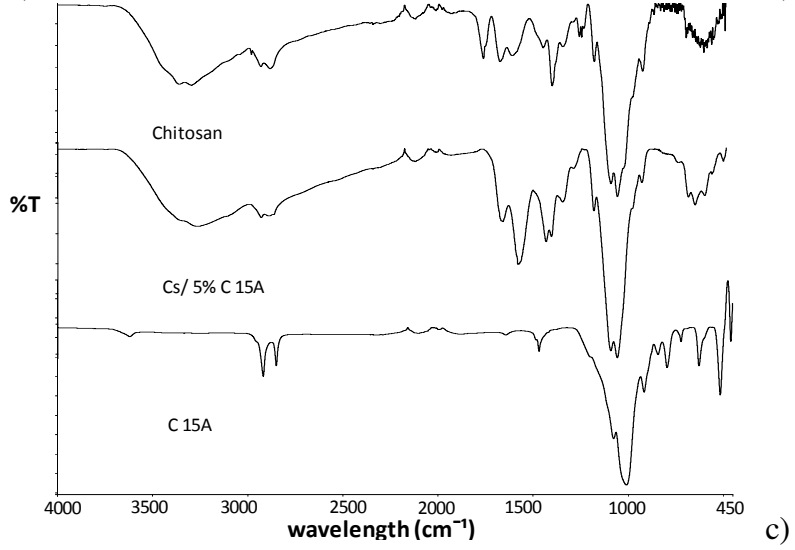

Figure 2: FTIR spectra of a) chitosan $/ 5 \% \mathrm{C} \mathrm{Na}$, b) chitosan/5\% C 10A, c) chitosan/5\% C 15A bionanocomposites, compared to those of chitosan and clay

\section{Morphological study using SEM}

Scanning electron microscopy (SEM) micrographs were used for further characterization of the nanocomposites. While the surface of chitosan was smooth and irregular, the bionanocomposites had scattered clay particles on the surface, along with a layered and exfoliated texture. The micrographs in Figure 4 show the changes in the morphology of the nanocomposites. As seen in the SEM micrographs, the clay was dispersed in the polymer matrix. The increase in the clay amount resulted in a more rugged structure, with increased grain size and partial cracks on the surface of the nanocomposite. SEM micrographs show that the polymer dispersed into the clay layer. This exfoliated structure was in accordance with the XRD results. The homogenous dispersion of nanoparticles and the homogenous matrix in the SEM images demonstrate the presence of an exfoliated structure. ${ }^{17-21}$ SEM micrographs of Chitosan/C Na, Chitosan/C 10A and Chitosan/C 15A bionanocomposites, at $30000 \times, 10000 \times$ and $1000 \times$ magnification, are presented in Figure 4. 


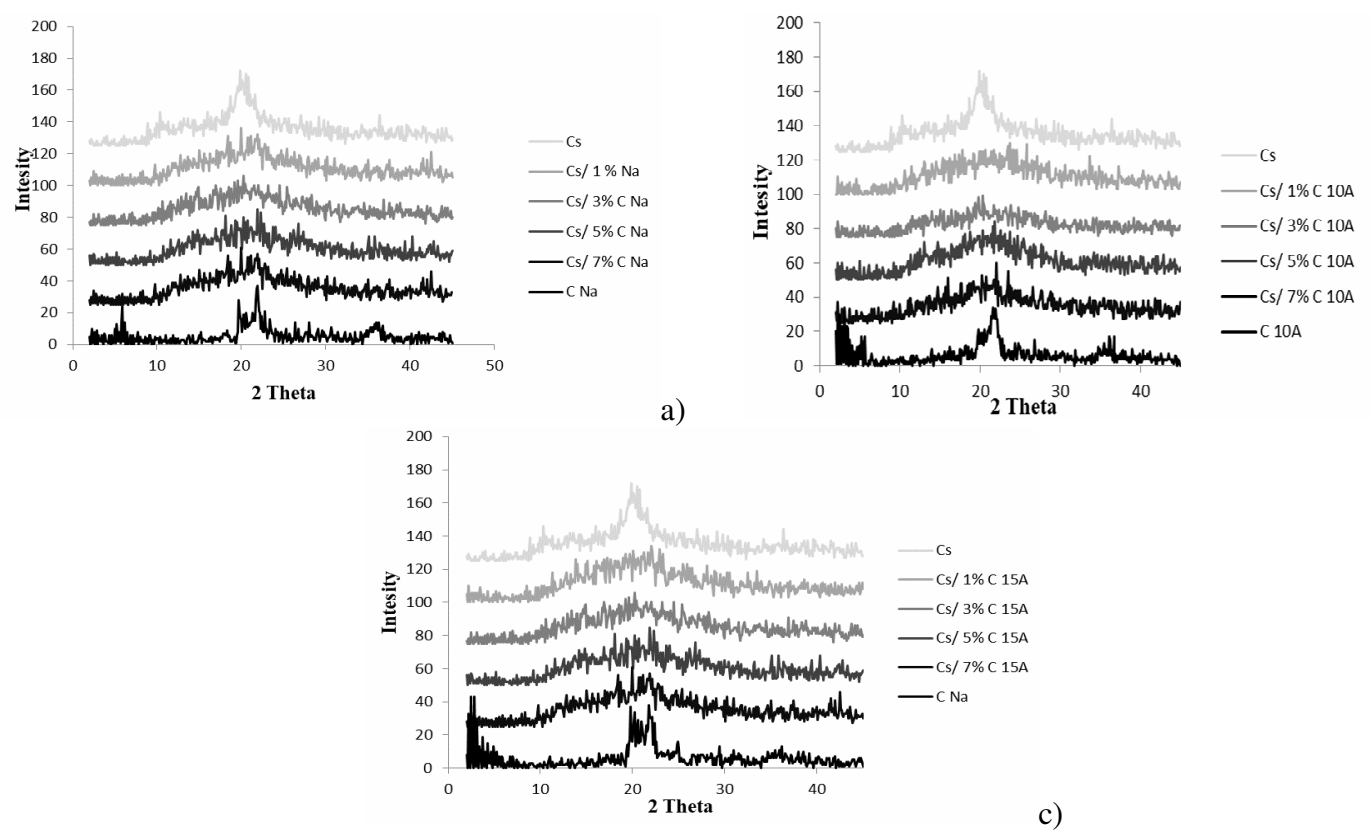

b)

Figure 3: XRD patterns of a) chitosan/C Na, b) chitosan/C 10A, c) and chitosan/C 15A bionanocomposites

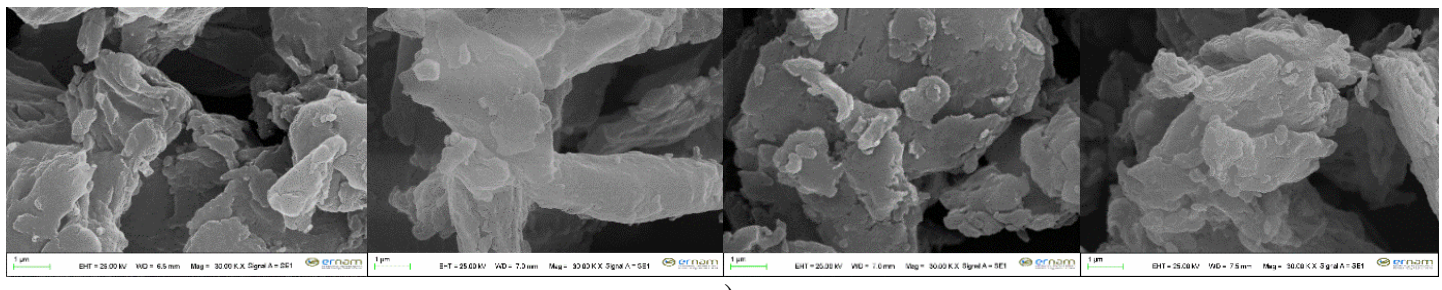

a)

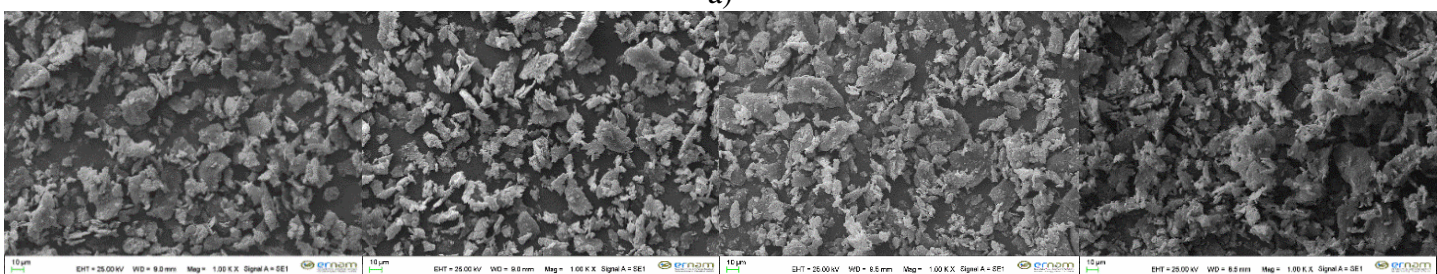

b)

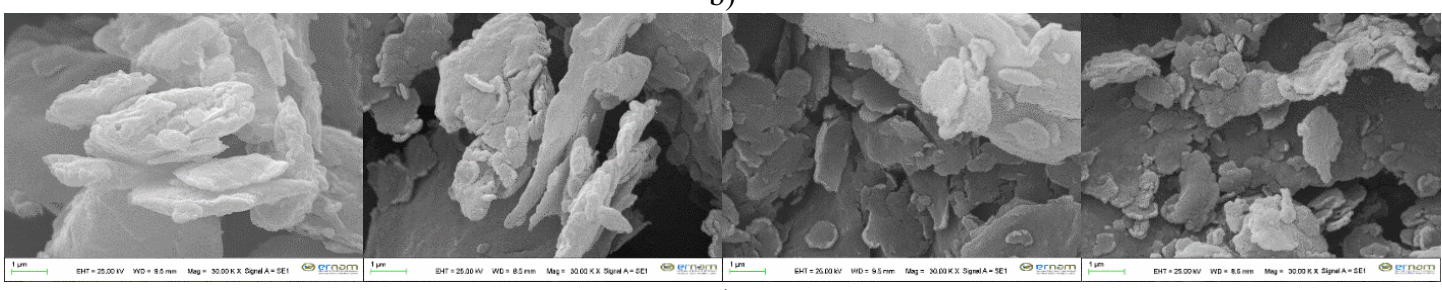

c)

Figure 4: SEM micrographs of a) chitosan/C Na, b) chitosan/C 10A, c) chitosan/C 15A bionanocomposites (1, 3, 5, 7\% clay added), respectively

\section{In vitro antibacterial activity}

Since the most common bacteria causing infection in humans are gram (+) S. aureus and gram (-) E. coli, these specific pathogenic microorganisms have been selected for in vitro studies. The antimicrobial activity of chitosan, clays and bionanocomposites was investigated qualitatively by the inhibition zone method and no antibacterial property of pure chitosan was detected. This may be caused by the fact that in the agar diffusion test of chitosan, the agar did not diffuse through the medium, so that only the 
organism in direct contact with the active site of chitosan was inhibited. ${ }^{1,13,15,18}$ Another reason can be that $S$. aureus and $E$. coli bacteria that were used may have gained resistance to chitosan. Bacteria can increase their resilience over time to survive. The unnecessary use or misuse of antimicrobial material in everyday life leads to the development of resistance in bacteria. ${ }^{22}$

Among the three clay types and the bionanocomposites, the highest biological activity belonged to C 10A. This behavior of the clays is probably related to the biocidal potentials of the ammonium salts. Cationic surfactants containing a long tail are more effective than two long chain

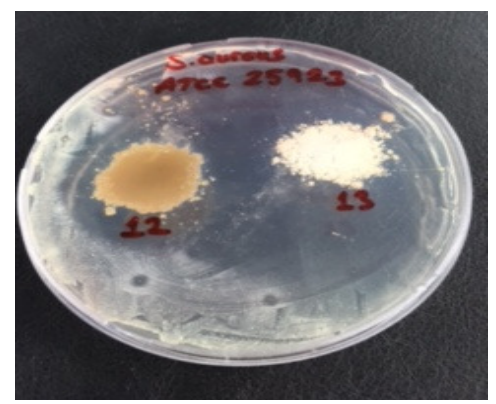

a)

Figure 5: Halo test results for chitosan/5\%
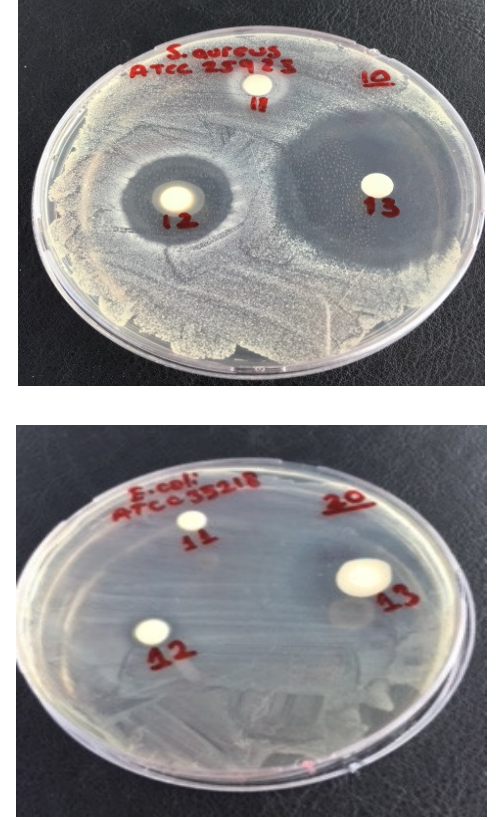

a)

b)

Figure 6: Agar dilution test results for chitosan, chitosan/5\% C 10A, C 10A organoclay and bionanocomposites

against a) S. aureus and b) E. coli

ones. Benzyl containing surfactants, such as $\mathrm{C}$ $10 \mathrm{~A}$, are more active than quaternary ammonium salts containing only the aliphatic tail. For this reason, the antimicrobial activities observed in organoclays are generally proportional to the biocidal activities of the cationic surfactants used for clay modification. ${ }^{23}$ Also, C $10 \mathrm{~A}$ clay and bionanocomposites showed more activity against $S$. aureus than against $E$. coli. Thus, as the amount of clay in the biocomponent increased, the biological activity also increased. All the results for the antimicrobial tests are presented in Figures 5-6 and Tables 2 and 3.

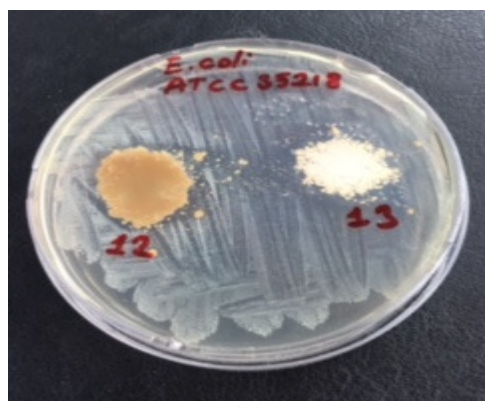

b)
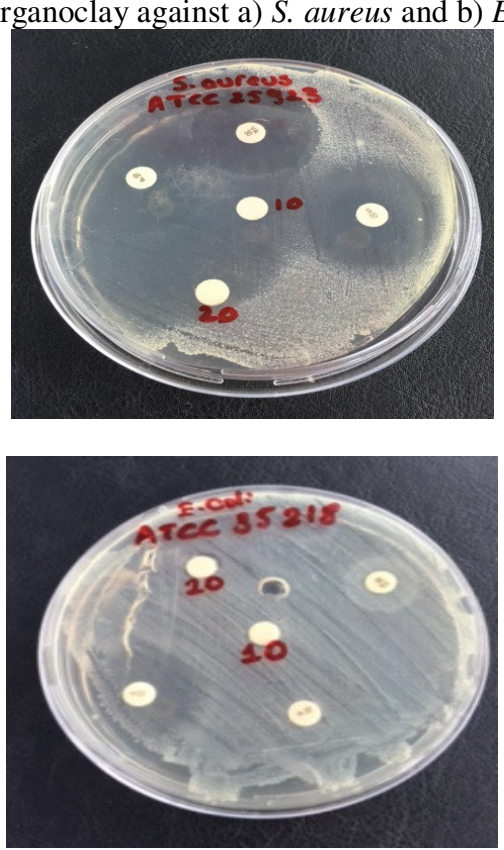


\section{NEVIN CANKAYA and RESUL SAHIN}

Table 2

Antimicrobial test results obtained by agar diffusion of C Na, C 15A clay and its bionanocomposites (mm)

\begin{tabular}{lcccccccccccccc}
\hline Bacteria & 1 & 2 & 3 & 4 & 5 & 6 & 7 & 8 & 9 & 10 & S & P & VA & DMSO \\
\hline S. aureus $(10 \mu \mathrm{L})$ ATCC 25923 & 0 & 0 & 0 & 0 & 0 & 9 & 7 & 7 & 7 & 10 & 29 & 30 & 28 & 0 \\
S. aureus $(20 \mu \mathrm{L})$ ATCC 25923 & 11 & 10 & 12 & 10 & 0 & 15 & 7 & 10 & 11 & 11 & 29 & & \\
E. coli $(10 \mu \mathrm{L})$ ATCC 35218 & 0 & 0 & 0 & 0 & 0 & 0 & 0 & 0 & 0 & 7 & 22 & 0 & 0 & 0 \\
E. coli $(20 \mu \mathrm{L})$ ATCC 35218 & 10 & 11 & 10 & 10 & 0 & 11 & 0 & 0 & 0 & 9 & & & \\
\end{tabular}

1) $\mathrm{C} \mathrm{Na}$ clay, 2) $\mathrm{Cs} / 1 \% \mathrm{C} \mathrm{Na}, 3) \mathrm{Cs} / 3 \% \mathrm{C} \mathrm{Na}, 4) \mathrm{Cs} / 5 \% \mathrm{C} \mathrm{Na}, 5) \mathrm{Cs} / 7 \% \mathrm{C} \mathrm{Na}, 6) \mathrm{C} 15 \mathrm{~A}$ clay, 7) $\overline{\mathrm{Cs} / 1 \% \mathrm{C}} \overline{15 \mathrm{~A},} 8 \mathrm{Cs} / 3 \% \mathrm{C} 15 \mathrm{~A}, 9) \mathrm{Cs} / 5 \% \mathrm{C} 15 \mathrm{~A}, 10) \mathrm{Cs} / 7 \% \mathrm{C} 15 \mathrm{~A}$

Table 3

Antimicrobial test results obtained by agar diffusion of chitosan and C 10A clay and its bionanocomposites (mm)

\begin{tabular}{|c|c|c|c|c|c|c|c|c|c|c|c|c|c|c|c|c|c|c|c|c|c|c|c|}
\hline Bacteria & & hitc & & & $\% \mathrm{C}$ & & & $\% \mathrm{C}$ & & & $\% \mathrm{C}$ & & & $\% \mathrm{C}$ & & & $0 \mathrm{~A}$ & & $\mathrm{~S}$ & $\mathrm{P}$ & VA & DA & DMSO \\
\hline$\mu \mathrm{L}$ & 5 & 10 & 20 & 5 & 10 & 20 & 5 & 10 & 20 & 5 & 10 & 20 & 5 & 10 & 20 & 5 & 10 & 20 & & & & & \\
\hline $\begin{array}{l}\text { S. aureus } \\
\text { ATCC } 25923\end{array}$ & 0 & 0 & 0 & 10 & 10 & 11 & 13 & 14 & 17 & 18 & 21 & 25 & 32 & 41 & 43 & 35 & 40 & 45 & 29 & 37 & 28 & 30 & 0 \\
\hline $\begin{array}{l}\text { E. coli } \\
\text { ATCC } 35218\end{array}$ & 0 & 0 & 0 & 0 & 0 & 0 & 0 & 0 & 0 & 0 & 0 & 8 & 18 & 21 & 29 & 14 & 20 & 28 & 22 & 9 & 0 & 0 & 0 \\
\hline
\end{tabular}




\section{Thermal analysis using TGA/DTA}

Thermogravimetric analysis (TGA) helps determine the thermal stability of polymer/clay nanocomposites and provides information about their thermal behavior. The thermal behaviors of chitosan, clay types and chitosan/clay bionanocomposites with various percentages of added clay have been determined by TGA. The samples were heated in nitrogen gas atmosphere, at a heating rate of $10{ }^{\circ} \mathrm{C} / \mathrm{min}$ from room temperature to $550{ }^{\circ} \mathrm{C}$, and their thermograms were analyzed.

Up to $50{ }^{\circ} \mathrm{C}$, the moisture in clay (pore water, adsorbed water, crystallized water, depending on the structure) evaporates. This process is called dehydration. Following dehydration, hydroxyl $(\mathrm{OH})$ groups bonded to the crystal structure are removed until the temperature reaches $900{ }^{\circ} \mathrm{C}$, which is called dehydroxylation. Analyzing the TGA results of $\mathrm{C} \mathrm{Na}$ clay from this perspective, it may be seen that dehydration resulting from the evaporation of adsorbed water and crystallized water in the clay continued until $550{ }^{\circ} \mathrm{C}$ (Fig. 7)..$^{24,25}$

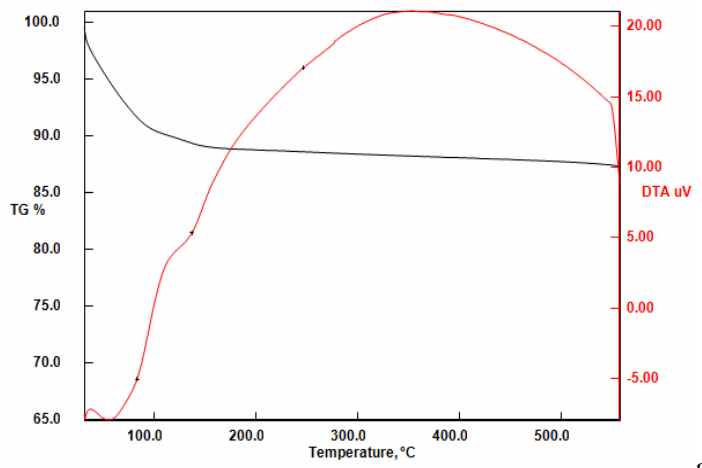

Since dehydroxylation of unmodified clays is usually observed at higher temperatures, no dehydroxylation step was observed in $\mathrm{C} \mathrm{Na}$ clay. The type of surface active material determines the mass loss, which affects the degradation steps in modified clays. ${ }^{17-19,21,26}$ When the TGA results of C 10A are analyzed, it can be observed that the first degradation step occurred at $170{ }^{\circ} \mathrm{C}$, the second - at $238{ }^{\circ} \mathrm{C}$ and final degradation started at $334{ }^{\circ} \mathrm{C}$, thus the decomposition was completed in 3 steps (Table 4). The TGA results of C 15A clay reveal that the first degradation step occurred at $220{ }^{\circ} \mathrm{C}$, and the second started at $400{ }^{\circ} \mathrm{C}$, the degradation being completed in 2 steps. The number of degradation steps observed in modified clays may vary depending on the loss of surface active material. ${ }^{17-19,21,26}$ The TGA/DTA thermograms for $\mathrm{C} \mathrm{Na}, \mathrm{C} 10 \mathrm{~A}$ and $\mathrm{C} 15 \mathrm{~A}$ clays are presented in Figure 7, while some thermal values, such as the degradation temperature and mass loss percentages at different temperatures, are presented in Table 4 comparatively.

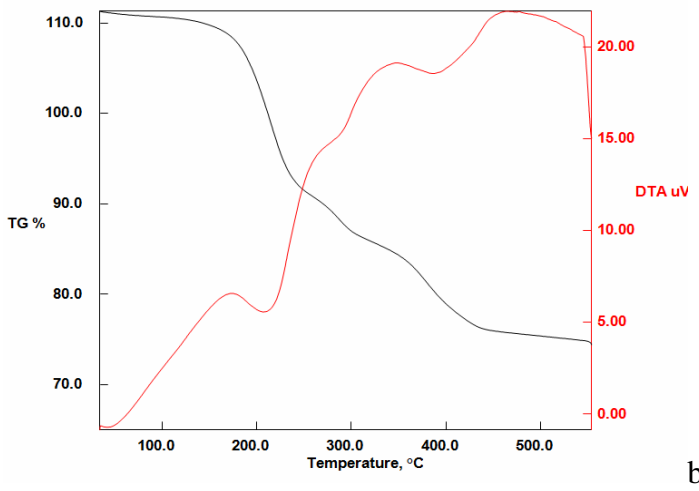

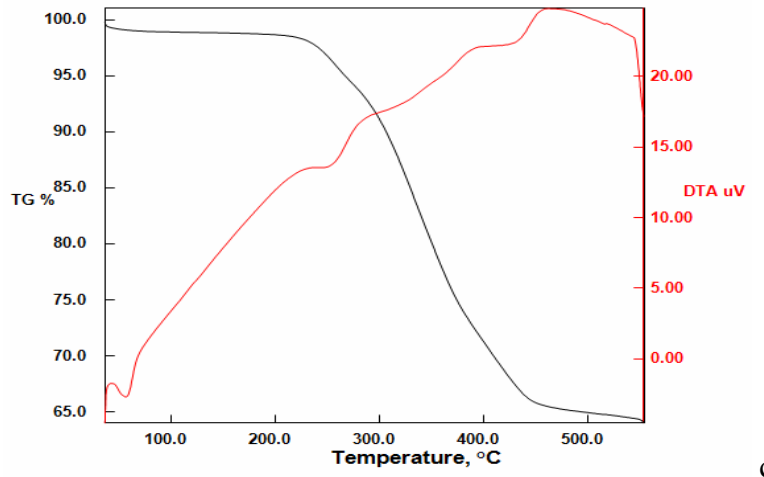

c)

Figure 7: TGA/DTA curves for a) $\mathrm{C} \mathrm{Na}$, b) C 10A, c) C 15A clays 


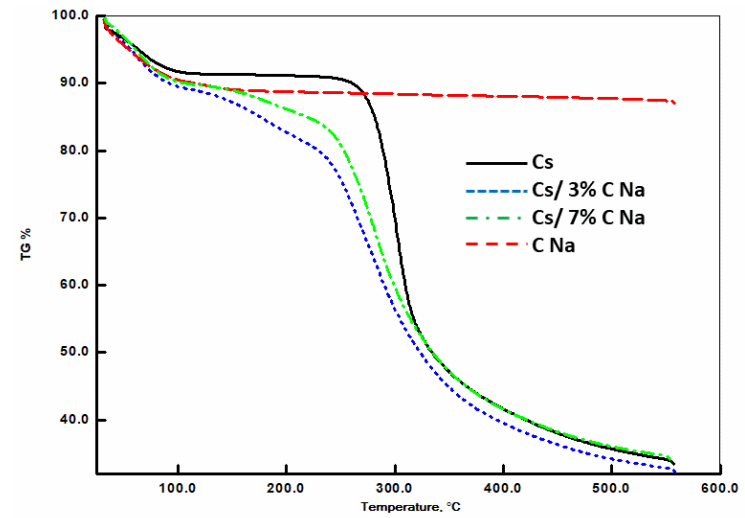

a)

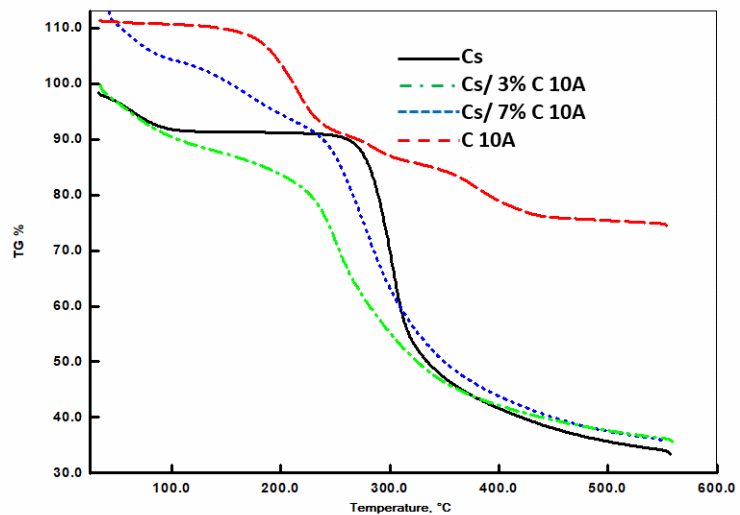

b)

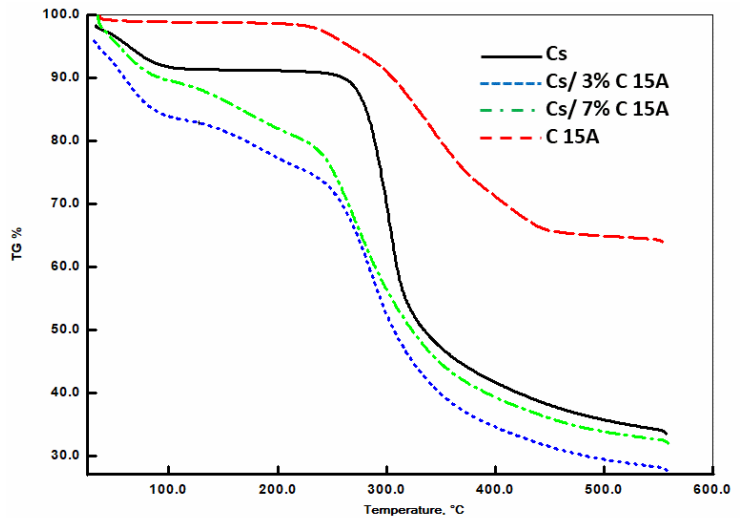

Figure 8: TGA curves for chitosan, $\mathrm{C} \mathrm{Na}, \mathrm{C} 10 \mathrm{~A}$ and C 15A clays and their bionanocomposites

Table 4

Thermal data for $\mathrm{C} \mathrm{Na}, \mathrm{C} 10 \mathrm{~A}$ and $\mathrm{C} 15 \mathrm{~A}$ clays obtained TGA/DTA

\begin{tabular}{lcccccc}
\hline Sample & $\begin{array}{c}\text { Max. } \\
\text { decomposition } \\
\text { temperature }\left({ }^{\circ} \mathrm{C}\right)\end{array}$ & $\begin{array}{c}\text { Temperature of } \\
10 \% \text { weight } \\
\text { loss }\left({ }^{\circ} \mathrm{C}\right)\end{array}$ & $\begin{array}{c}\text { Temperature of } \\
20 \% \text { weight } \\
\text { loss }\left({ }^{\circ} \mathrm{C}\right)\end{array}$ & $\begin{array}{c}\text { \% Weight } \\
\text { loss } \\
\left(300{ }^{\circ} \mathrm{C}\right)\end{array}$ & $\begin{array}{c}\text { \% Weight } \\
\text { loss } \\
\left(400{ }^{\circ} \mathrm{C}\right)\end{array}$ & $\begin{array}{c}\% \text { Residue } \\
\left(550{ }^{\circ} \mathrm{C}\right)\end{array}$ \\
\hline $\mathrm{C} \mathrm{Na}$ & 135 & 116 & - & 11 & 22 & 88 \\
$\mathrm{C} \mathrm{10A}$ & $209,288,386$ & 271 & 349 & 13 & 21 & 75 \\
$\mathrm{C} \mathrm{15A}$ & 250,428 & 305 & 355 & 9 & 29 & 36 \\
\hline
\end{tabular}

Table 5

TGA data for chitosan and $\mathrm{C} \mathrm{Na}, \mathrm{C} 10 \mathrm{~A}$ and C 15A bionanocomposites

\begin{tabular}{lccccc}
\hline Sample & $\begin{array}{c}\text { Max. } \\
\text { decomposition } \\
\text { temperature }\left({ }^{\circ} \mathrm{C}\right)\end{array}$ & $\begin{array}{c}\text { Temperature } \\
\text { of } 50 \% \text { weight } \\
\text { loss }\left({ }^{\circ} \mathrm{C}\right)\end{array}$ & $\begin{array}{c}\text { \%Weight } \\
\text { loss } \\
\left(300{ }^{\circ} \mathrm{C}\right)\end{array}$ & $\begin{array}{c}\text { \% Weight } \\
\text { loss } \\
\left(400{ }^{\circ} \mathrm{C}\right)\end{array}$ & $\begin{array}{c}\text { \% Residue } \\
\left(550{ }^{\circ} \mathrm{C}\right)\end{array}$ \\
\hline Chitosan & 273 & 335 & 30 & 58 & 34 \\
$\mathrm{Cs} / 3 \% \mathrm{C} \mathrm{Na}$ & 243 & 324 & 43 & 61 & 32 \\
$\mathrm{Cs} / 7 \% \mathrm{C} \mathrm{Na}$ & 249 & 336 & 40 & 58 & 35 \\
$\mathrm{Cs} / 3 \% \mathrm{C} \mathrm{10A}$ & 240 & 325 & 45 & 57 & 37 \\
$\mathrm{Cs} / 7 \% \mathrm{C} \mathrm{10A}$ & 244 & 350 & 37 & 55 & 36 \\
$\mathrm{Cs} / 3 \% \mathrm{C} \mathrm{15A}$ & 243 & 306 & 48 & 66 & 30 \\
$\mathrm{Cs} / 7 \% \mathrm{C} 15 \mathrm{~A}$ & 245 & 320 & 45 & 61 & 33 \\
\hline
\end{tabular}

When the thermal behaviors of the bionanocomposites are compared, it is observed that the composites containing clay have lower mass loss percentage and better thermal stability, compared to chitosan. These thermal changes prove that chitosan chains break in the clay 
galleries and form bionanocomposites. The nanodispersion of chitosan molecules in the silicate layers limits thermal movement, which increases thermal stability. It was observed that the thermal stability of bionanocomposites formed with clay increased with the increasing amount of clay in the composite, resulting in a thermal barrier. ${ }^{10,21,26}$ The bionanocomposites synthesized with other types of clay have also yielded similar results. The thermograms obtained for the bionanocomposites are presented in Figure 8, while some thermal data are given in Table 5.

\section{Equilibrium swelling studies}

The swelling behavior of the chitosan, clays and bionanocomposites was studied at $25{ }^{\circ} \mathrm{C}$, pH 7.4, after immersion for 1, 3, 6 and 9 hours into distilled water until swelling reached an equilibrium state. It has been observed that the highest swelling occurred in $\mathrm{C} \mathrm{Na}$ clay and the least in $\mathrm{C} 15 \mathrm{~A}$ after saturation. Comparing the swelling behavior between chitosan and the different clay types, the following order has been established Chitosan $>\mathrm{C} \mathrm{Na}>\mathrm{C} 10 \mathrm{~A}>\mathrm{C} 15 \mathrm{~A}$ (Fig. 9). $\mathrm{Cs} / \mathrm{C} \quad \mathrm{Na}$ and $\mathrm{Cs} / \mathrm{C} \quad 15 \mathrm{~A}$ bionanocomposites took nearly 9 hours to saturate, while, $\mathrm{Cs} / \mathrm{C} 10 \mathrm{~A}$ bionanocomposites took nearly 1 hour. The swelling capacities of $\mathrm{C}$ $\mathrm{Na}, \mathrm{C} 10 \mathrm{~A}, \mathrm{C} 15 \mathrm{~A}$ and the bionanocomposites, with respect to time, are illustrated in Figure 10. Swelling has been noted to be inversely proportional to the amount of clay (directly proportional to the amount of chitosan) in all the bionanocomposites, because of the hydrophilic property provided by groups such as $\mathrm{OH}$ and $\mathrm{NH}_{2}$ in the structure of chitosan. ${ }^{18}$ Since $\mathrm{C}$ Na presents the highest swelling, chitosan/C Na turned out to be one of the composites that swelled the most, as may be remarked in Figure 11.

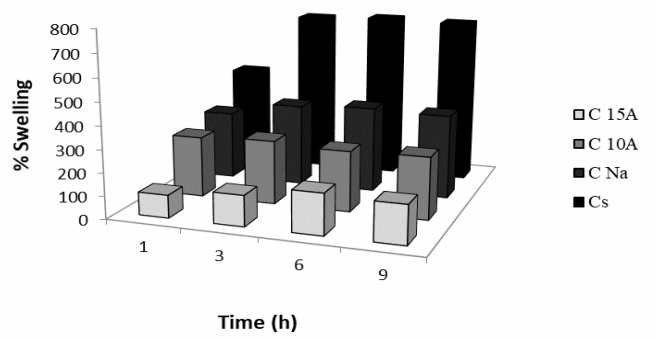

Figure 9: Swelling behavior of chitosan, C Na, C 10A and C 15A clays

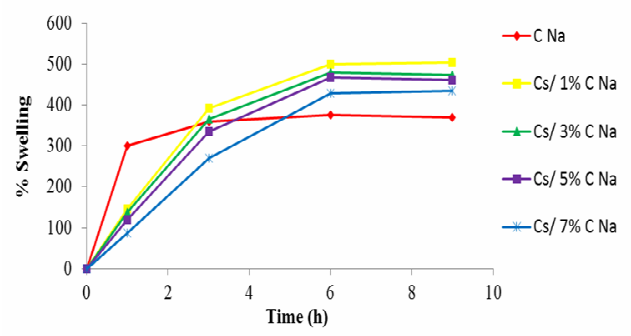

a)
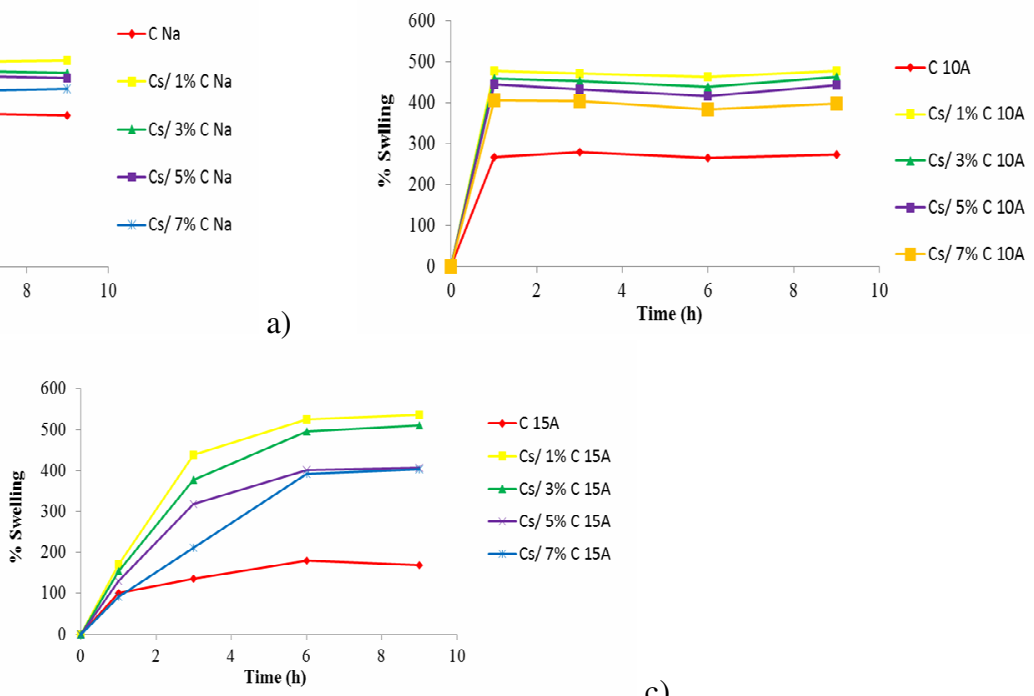

b)

c)

Figure 10: Swelling behavior of a) chitosan/C Na, b) chitosan/C 10A and c) chitosan/C 15A bionanocomposites, respectively 


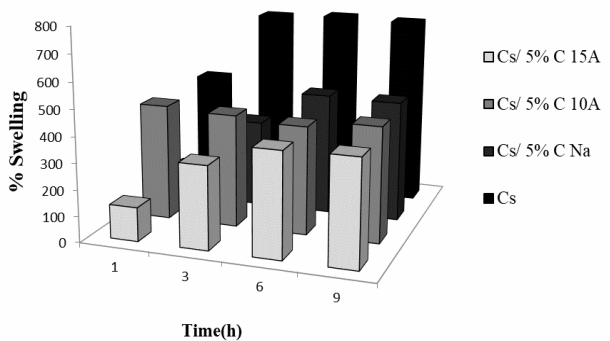

Figure 11: Swelling behavior of chitosan, chitosan/5\% C Na/C 10A/C 15A bionanocomposites, respectively

\section{CONCLUSION}

The characterization of bionanocomposites prepared with chitosan biopolymer and three different clay types, in various percentages, was performed chemically by FTIR, physically by XRD and SEM, and thermally by TGA/DTA. The antimicrobial properties of the clays and bionanocomposites were investigated against $S$. aureus and E. coli. Swelling tests on the clays and bionanocomposites were also carried out.

According to XRD patterns and SEM micrographs, the chitosan/clay bionanocomposites prepared by the blending method had an exfoliated structure. TGA results showed that unmodified $\mathrm{C}$ Na clay had a higher thermal stability, compared to the modified $\mathrm{C}$ $10 \mathrm{~A}$ and $\mathrm{C} 15 \mathrm{~A}$ clays. The thermal stabilities of the bionanocomposites were observed to increase with the rising amount of clay added into chitosan. Thus, novel heat resistant bionanocomposite systems have been developed in this study by incorporating chitosan into clay material.

Swelling experiments proved that chitosan was the most water absorbent, while $\mathrm{C} 15 \mathrm{~A}$ clay was the least (chitosan $>\mathrm{C} \mathrm{Na}>\mathrm{C} \mathrm{10A}>\mathrm{C} 15 \mathrm{~A}$ ). Swelling was inversely proportional to the amount of clay and directly proportional to the amount of chitosan in all the bionanocomposites. Further swelling studies may be performed to examine the effects of temperature, $\mathrm{pH}$ and solvent, as well as time, on the swelling behavior of the materials. Moreover, studies on metal ions and paint removal from water may also be performed.

The antimicrobial activity of chitosan, the clays and their bionanocomposites against $S$. aureus and E. coli was investigated. Although previous studies had reported on the antibacterial properties of chitosan, in this study no such activity was observed and it was argued that $S$. aureus and E. coli may have developed resistance to the type of chitosan we used. Among the three clay types and their bionanocomposites, the most biologically active was C 10A. The effect of C $10 \mathrm{~A}$ clay and its bionanocomposite against $S$. aureus was greater than against $E$. coli. These results reveal that polymer/clay biocomposites, which can be used in many fields, such as textile, furniture, paints and electronics, can also be prepared using antimicrobial sterile clay. The chitosan polymer/clay biocomposites thus developed would have an even wider application area.

ACKNOWLEDGEMENT: The authors would like to thank the Usak University Research Fund for financial support of this work (2017/TP001).

\section{REFERENCES}

1 J. Roul, R. Mohapatra and S. K. Sahoo, Pak. J. Pharm. Sci., 29, 1145 (2016), http://www.pjps.pk/wpcontent/uploads/pdfs/29/4/Paper-6.pdf

2 S. Pandey and S. B. Mishra, J. Coll. Inter. Sci., 361 , 509

(2011), https://doi.org/10.1016/j.jcis.2011.05.031

3 P. K. Swain, M. Das and P. L. Nayak, Int. J. Plant Anim. Env. Sci., 6, $245 \quad$ (2016), https://www.ijpaes.com/admin/php/uploads/932_pdf.p df

4 A. Demir and N. Seventekin, Electronic J. Tex. Tech., $\quad 3, \quad 92 \quad$ (2009), http://www.tekstildershanesi.com.tr/makaleler/kitinkitosan-ve-genel-kullanim-alanlari.html

5 F. Chivrac, E. Pollet and L. Averous, Mater. Sci. $\begin{array}{lllll}\text { Eng., } & \mathrm{R} & \mathbf{6 7}, & 1 & \text { (2009), }\end{array}$ https://doi.org/10.1016/j.mser.2009.09.002

6 Y. X. Ren and M. A. Hanna, J. Appl. Polym. Sci., 99, 1684 (2006), https://doi.org/10.1002/app.22664

7 O. I. H. Dimitry, N. A. Mansour and A. L. G. Saad, WASET, $\quad \mathbf{1 0}, 283 \quad$ (2016), https://waset.org/Publication/influence-of-organicmodifier-loading-on-particle-dispersion-ofbiodegradable-polycaprolactone-montmorillonitenanocomposites-/10006062

8 M. Flieger, M. Kantorova, A. Prell, T. Rezanka and J. Votruba, Folia Microbiol., 48, 27 (2003), https://link.springer.com/article/10.1007/BF02931273 
9 M. P. M. Costa, I. L.M. Ferreira and M. T. M. Cruz, Carbohyd. Polym., 46, 123 (2016), https://doi.org/10.1016/j.carbpol.2016.03.025

10 E. Günister, D. Pestreli, C. H. Unlu, O. Atici and N. Gungor, Carbohyd. Polym., 67, 358 (2007), https://doi.org/10.1016/j.carbpol.2006.06.004

11 S. F. Wang, L. Shen, Y. J. Tong, L. Chen, I. Y. Phang et al., Polym. Degrad. Stabil., 90, 123 (2005), https://doi.org/10.1016/j.polymdegradstab.2005.03.001 12 M. Darder, M. Colilla and E. Ruiz-Hitzky, Chem. Mater., $\quad \mathbf{1 5}, \quad 3774 \quad$ (2003), https://doi.org/10.1021/cm0343047

${ }_{13}$ F. B. Karel, A. S. Koparal and E. Kaynak, $A d v$. Mat. Sci. Eng., 2015, 409078 (2015), http://dx.doi.org/10.1155/2015/409078

14 M. Talu, E. Uzluk and B. Yuksel, Macromol. Symp., $\quad 297, \quad 188 \quad$ (2010), https://doi.org/10.1002/masy.200900140

15 R. B. Bostancioğlu, C. Peksen, H. Genc, M. Gürbüz, F. B. Karel et al., Biomed. Mater., 10, 045024 (2015), https://doi.org/10.1088/17486041/10/4/045024

16 C. Paluszkiewicz, E. Stodolak, M. Hasika and M. Blazewicz, Spectrochem. Acta P.A., 79, 84 (2011), https://doi.org/10.1016/j.saa.2010.08.053

17 A. Altınısık, Y. Seki and K. Yurdakoç, Polym. Compos., $\quad 30, \quad 1035 \quad$ (2009), https://doi.org/10.1002/pc.20651
18 B. H. N. Reddy, V. V. Lakshmi, K. R. V. Mahesh, M. Mylarappa, N. Raghavendra et al., Nanosystems: Phys. Chem. Math., 7, 667 (2016), doi:10.17586/22208054-2016-7-4-667-674

19 C. G. Potarniche, C. G. Potarniche, Z. Vuluga, D. Donescu, J. C. Christiansen et al., Surf. Interface Anal., 44, 200 (2012), https://doi.org/10.1002/sia.3797

20 J. Roul, S. K. Sahoo and R. Mohapatra, Int. J. Nano Dimens., 4 135 https://doi.org/10.7508/IJND.2013.02

21 A. Delibas and M. Alparslan, Turk. J. Chem., 39, 630 (2015), https://doi.org/10.3906/kim-1410-35

$22 \mathrm{https} / / /$ tr.khanacademy.org/science/health-andmedicine/current-issues-in-health-and-

medicine/antibiotics-and-antibiotic-resistance/a/whatis-antibiotic-resistance

${ }^{23}$ R. Nigmatullin, F. Gao and V. J. Konovalova, Mater. Sci., 43, $5728 \quad$ (2008), https://doi.org/article/10.1007/s10853-008-2879-4

${ }_{24}$ H. Noyan., M. Önal and Y. Sarıkaya, J. Therm. Anal. Calorim., 91, 299 (2007), https://doi.org/10.1007/s10973-007-8260-z

25 S. Sperinck, P. Raiteri, N. Marks and K. Wright, J. Mater. Chem., 21, $2118 \quad$ (2011), https://doi.org/10.1039/C0JM01748E

26 A. Kurt and M. Koca, J. Eng. Res., 4, 46 (2016), http://kuwaitjournals.org/jer/index.php/JER/article/vie w/1357 